\title{
Simultaneous Determination of B Group Vitamins in Supplemented Food Products by High Performance Liquid Chromatography-Diode Array Detection
}

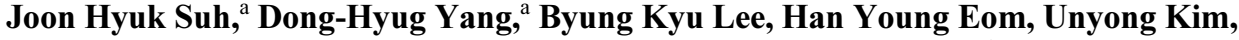 \\ Junghyun Kim, Hyeyeon Lee, and Sang Beom Han* \\ Department of Pharmaceutical Analysis, College of Pharmacy, Chung-Ang University, Seoul 156-756, South Korea \\ EE-mail:hansb@cau.ac.kr \\ Received May 12, 2011, Accepted June 26, 2011
}

\begin{abstract}
A simple HPLC-DAD method was developed and validated to determine B group vitamin content (thiamine, riboflavin, nicotinamide, pantothenic acid, pyridoxine and folic acid) in supplemented food samples, i.e., infant formula, cereal, low-calorie food, a multi-vitamin pill and a vitamin drink. In this study, the most significant advantages were simultaneous determination of the six B group vitamins in various food matrices and a small number of sample treatment steps that required only an organic solvent, acetonitrile. Moreover, this method prevents reduction of column durability, because the mobile phase does not contain ion-pairing reagents. Analytes were separated on a Develosil RPAQUEOUS $\mathrm{C}_{30}(4.6 \mathrm{~mm} \times 250 \mathrm{~mm}, 5 \mu \mathrm{m}$ particle size $)$ column with a gradient elution of acetonitrile and $20 \mathrm{mM}$ phosphate buffer $(\mathrm{pH} 3.0)$ at a flow rate between 0.8 and 1.0 $\mathrm{mL} / \mathrm{min}$. Detection was performed at $275 \mathrm{~nm}$, except for that of pantothenic acid $(205 \mathrm{~nm})$. The calibration curves for all six vitamins showed good linearity with correlation coefficients $\left(r^{2}\right)$ higher than 0.995 . The developed method was validated with respect to linearity, intra- and inter-day accuracy and precision, limit of quantification (LOQ), recovery and stability. The method showed good precision and accuracy, with intra- and inter-assay coefficients of variation less than $15 \%$ at all concentrations. The recovery was carried out according to the standard addition procedure, with yields ranging from 89.8 to $104.4 \%$. This method was successfully applied to the determination of vitamin B groups in supplemented food products.
\end{abstract}

Key Words : B Group vitamins, Supplemented food products, High performance liquid chromatography (HPLC), Diode array detection (DAD), Validation

\section{Introduction}

Vitamins are well-known organic compounds that are absolutely essential to maintain good health, and normal growth and functioning in human and animal bodies. ${ }^{1-4}$ The B group vitamins are very important water-soluble vitamins that play vital roles in metabolism, and their absences are associated with serious diseases. ${ }^{5,6}$ The human diet sometimes does not meet the daily requirements of vitamins necessary to maintain body functions and normal development. In these cases, fortified food products (infant formula, cereal, low-calorie food and drink) or pharmaceutical preparations (injection, tablet, capsule and syrup) supplement the necessary vitamins. All supplemented food products have to meet recommended dietary allowance (RDA) requirements for each vitamin. Vitamins, however, are relatively unstable and can be lost during food processing or storage under the influence of temperature, humidity and light. ${ }^{7}$ Therefore, a rapid and simple analytical determination of vitamin content in supplemented food products would be useful for many food laboratories, manufacturing plants and nutrition regulation authorities.

Current official analytical methods ${ }^{8,9}$ for determining B group vitamin contents are based on microbiological, chromato-

\footnotetext{
${ }^{a}$ These authors contributed equally to this work.
}

graphic or spectrophotometric techniques. Microbiological assays $^{10-12}$ have been used to analyze B group vitamins for many years, but they are no longer considered to be the gold standard in vitamin analysis because of their poor specificity and reproducibility. A few chromatographic methods that rely on colorimetric or fluorometric techniques are available from the Association of Analytical Communities (AOAC). ${ }^{13}$ It is important to note that many analytical methods are timeconsuming and sometimes not suitable for simultaneous determination of water-soluble vitamins with different chemical and physical properties.

Reverse-phase liquid chromatography (RP-LC) with ionpairing reagents (sodium dioctyl sulphosuccinate, trifluoroacetic acid, octanesulphonic acid and triethylamine) has been widely used to separate water-soluble vitamins because of better reproducibility at the desired retention time. ${ }^{14-17}$ Moreover, ion-pairing reagents improve the chromatographic resolution and peak shape, particularly by reducing peak tailing. These reagents can result in irreversible damage to column performance including a change in selectivity or longer equilibration times, due to adsorption of the ionpairing reagents onto the stationary phase. ${ }^{18}$ These changes may reduce column life.

New sample preparation methods have been introduced to determine water-soluble vitamins in various matrixes. Extraction techniques based on different acid treatments and 
enzymatic digestion such as hydrochloric acid, sulfuric acid, perchloric acid or amylase and taka-diastase ${ }^{19-30}$ have been developed, but the acids or enzymes require a long incubation (normally over 10-h) and high heat. Thus, these processes may decrease the recovery of unstable vitamins, such as folic acid. A simple precipitation of proteins with zinc acetate and phosphotungstic acid followed by centrifugation and filtration is sufficient for infant formula and beverages, ${ }^{31}$ but is not applicable to supplemented food products like cereals. Furthermore, heavy metals in the precipitation solution interact poorly with LC systems.

In the present study, the analysis of six B group vitamins, thiamine (vitamin $B_{1}, T$ ), riboflavin (vitamin $B_{2}, R F$ ), nicotinamide (vitamin $\mathrm{B}_{3}, \mathrm{NA}$ ), pantothenic acid (vitamin $\mathrm{B}_{5}, \mathrm{PA}$ ), pyridoxine (vitamin $\mathrm{B}_{6}, \mathrm{PN}$ ) and folic acid (vitamin $\mathrm{B}_{9}, \mathrm{FA}$ ), was optimized. A reverse-phase chromatographic technique using a $\mathrm{C}_{30}$-based stationary phase and a photodiode array detector (DAD) was employed without the use of ion-pairing reagents. The sample preparation was based on a simple protein precipitation with an organic solvent, acetonitrile. The procedure was successfully applied to the determination of the B group vitamins in supplemented food products, such as infant formula, cereal, low-calorie food, multi-vitamin pills and vitamin drinks. To the best of our knowledge, there is no single application for determining all B group vitamins within these various food matrices. Thus, the technique described here appears to be a powerful tool for analyzing vitamins in food products.

\section{Experimental}

Materials and Instruments. Thiamine, riboflavin, pantothenic acid and folic acid were purchased from Fluka (Steinheim, Germany). Pyridoxine and potassium phosphate monobasic (99\%) were from Sigma-Aldrich (St. Louis, MO, USA) and nicotinamide was from TGI (Tokyo, Japan). Acetonitrile, water and phosphoric acid $(85 \%)$ were of HPLC grade from Merck (Darmstadt, Germany). Nylon membrane filters $(0.45$ and $0.22 \mu \mathrm{m})$ were purchased from Whatman (Maidstone, England). All other reagents were of analytical grade except those for HPLC, which were of HPLC grade.

A Waters HPLC system (Waters, Milford, MA, USA), equipped with a 1525 pump, a 717 plus autosampler, a CO965 column oven (Jasco, Tokyo, Japan) and a 966 photodiode array detector (Waters), was used. Data was collected using Empower software (Ver. 5.00.00.00, Waters Corp.).

Samples. Infant formula, cereal, low-calorie food, multivitamin pills and vitamin drinks were purchased from different supermarkets in Seoul, South Korea. The nutritional components of these foods are listed in Table 1.

Chromatographic Conditions for Sample Analysis. Reverse-phase chromatographic columns; Luna $\mathrm{C}_{5}(4.6 \mathrm{~mm}$ $\times 150 \mathrm{~mm}, 5 \mu \mathrm{m}$ particle size, Phenomenex, Torrance, CA, USA), Luna $\mathrm{C}_{8}(4.6 \mathrm{~mm} \times 150 \mathrm{~mm}, 5 \mu \mathrm{m}$ particle size, Phenomenex), Synergi Polar-RP (4.6 mm $\times 150 \mathrm{~mm}, 4 \mu \mathrm{m}$ particle size, Phenomenex), Ascentis Express $\mathrm{C}_{18}(4.6 \mathrm{~mm} \times$

Table 1. Tested food samples

\begin{tabular}{|c|c|c|}
\hline Food sample & Form & Labelled vitamin content $(\mu \mathrm{g} / \mathrm{g})$ \\
\hline Infant formula 1 & Powder & T (4.5), RF (6), NA (50), PA (30), PN (3), FA (1) \\
\hline Infant formula 2 & Powder & T (6), RF (8), NA (60), PA (28), PN (6), FA (0.8) \\
\hline Infant formula 3 & Powder & T (10), RF (10), NA (60), PA (30), PN (4), FA (0.5) \\
\hline Infant formula 4 & Powder & T (5), RF (9), NA (53), PA (30), PN (5), FA (1) \\
\hline Infant formula 5 & Powder & T (3), RF (6), NA (50), PA (35), PN (3), FA (1) \\
\hline Infant formula 6 & Powder & T (5), RF (8), NA (58), PA (50), PN (3.15), FA (1) \\
\hline Infant formula 7 & Powder & T (2.3), RF (4.6), NA (37), PA (23), PN (2.3), FA (0.8) \\
\hline Infant formula 8 & Powder & $\mathrm{T}$ (2.3), RF (4.6), NA (40), PA (24), PN (2.3), FA (0.8) \\
\hline Infant formula 9 & Powder & $\mathrm{T}$ (5.29), RF (11.66), NA (55.2), PA (33.2), PN (3.19), FA (0.9) \\
\hline Infant formula 10 & Powder & T (4), RF (6), NA (50), PA (30), PN (4), FA (1) \\
\hline Cereal 1 & Solid & T (8.33), RF (10), NA (108.3), PN (12.67), FA (2.08) \\
\hline Cereal 2 & Solid & T (8), RF (9.5), NA (106.5), PN (9.5), FA (1.55) \\
\hline Cereal 3 & Solid & $\mathrm{T}$ (8.33), RF (10), NA (108.3), PN (12.67), FA (2.08) \\
\hline Low-calorie food 1 & Solid & $\mathrm{T}$ (3.95), RF (4.74), NA (51.3), PN (5.92), FA (0.99) \\
\hline Low-calorie food 2 & Solid & T (3.95), RF (4.74), NA (51.3), PN (5.92), FA (0.99) \\
\hline Low-calorie food 3 & Solid & T (3.95), RF (4.74), NA (51.3), PN (5.92), FA (0.99) \\
\hline Multi-vitamin pill 1 & Tablet & T (310), RF (425), NA (2255), PN (675), FA (35) \\
\hline Multi-vitamin pill 2 & Tablet & RF (570), PN (713) \\
\hline Multi-vitamin pill 3 & Tablet & T (3200), RF (1867), PA (2534), PN (2534) \\
\hline Multi-vitamin pill 4 & Tablet & FA (444) \\
\hline Vitamin drink 1 & Liquid & NA (30), PN (4.5) \\
\hline Vitamin drink 2 & Liquid & RF (6.6), NA (24.3), PA (9.5), PN (2.8) \\
\hline Vitamin drink 3 & Liquid & NA (30), PN (4.5) \\
\hline
\end{tabular}


$150 \mathrm{~mm}, 2.7 \mu \mathrm{m}$ particle size, Supelco, St. Louis, MO, USA), Hypersil Gold $\mathrm{C}_{18}(4.6 \mathrm{~mm} \times 250 \mathrm{~mm}, 5 \mu \mathrm{m}$ particle size, Thermo, Waltham, MA, USA) and Develosil RPAQUEOUS $\mathrm{C}_{30}(4.6 \mathrm{~mm} \times 250 \mathrm{~mm}, 5 \mu \mathrm{m}$ particle size, Phenomenex, Tokyo, Japan) were tested for their separation abilities of B group vitamins. Optimization of the HPLC mobile phase was performed by applying several parameter modifications (concentration of mobile phase modifiers, $\mathrm{pH}$ and gradient elution profile) to obtain proper separation of the six B group vitamins. Separation was carried out using a gradient elution on a Develosil RPAQUEOUS $\mathrm{C}_{30}$ column at $30^{\circ} \mathrm{C}$. The mobile phase was $20 \mathrm{mM}$ potassium phosphate $\mathrm{pH} 3.0$ (solvent A) and $50 \%$ acetonitrile $(\mathrm{v} / \mathrm{v})$ in $20 \mathrm{mM}$ potassium phosphate $\mathrm{pH} 3.0$ (solvent $\mathrm{B}$ ). The flow rate was between 0.8 and $1.0 \mathrm{~mL} / \mathrm{min}$. Injection volume was $20 \mu \mathrm{L}$, and the autosampler temperature was $5{ }^{\circ} \mathrm{C}$ to avoid degradation. All vitamins were detected at $275 \mathrm{~nm}$, except for PA, which was detected at $205 \mathrm{~nm}$.

Preparation of Standard Solutions. Stock solutions of T, RF, PN and FA $(100 \mu \mathrm{g} / \mathrm{mL})$ were prepared by dissolving 5 $\mathrm{mg}$ of each compound in $50 \mathrm{~mL}$ of deionized water. The PA $(500 \mu \mathrm{g} / \mathrm{mL})$ and NA $(1000 \mu \mathrm{g} / \mathrm{mL})$ stock solutions were prepared by dissolving $5 \mathrm{mg}$ of each compound in $10 \mathrm{~mL}$ and $5 \mathrm{~mL}$ of deionized water, respectively. All stock solutions were stored in the dark at $-20^{\circ} \mathrm{C}$. Working standard solutions were prepared daily by mixing the stock solutions in the appropriate proportions and diluting them with deionized water. The standards contained 0.1-5.0 $\mu \mathrm{g} / \mathrm{mL}$ FA, $0.2-10.0 \mu \mathrm{g} / \mathrm{mL}$ T, RF and PN, 0.5-25.0 $\mu \mathrm{g} / \mathrm{mL}$ PA and 2.0$100.0 \mu \mathrm{g} / \mathrm{mL}$ NA. The working standard solutions were stored at $4{ }^{\circ} \mathrm{C}$ in the dark. All solutions were filtered through a $0.45 \mu \mathrm{m}$ nylon membrane filter prior to HPLC analysis.

Sample Preparation and Quantification. For infant formula, cereal and low-calorie foods, $0.5 \mathrm{~g}$ of sample was placed in a $15 \mathrm{~mL}$ plastic tube with $2.0 \mathrm{~mL}$ of water. The mixtures were homogenized for $3 \mathrm{~min}$ at room temperature, and $6.0 \mathrm{~mL}$ of acetonitrile was added. The tubes were centrifuged at $4000 \mathrm{rpm}$ for $10 \mathrm{~min}$, and the supernatants were evaporated to dryness in a rotary vacuum evaporator. For infant formula, the residue was dissolved in $5.0 \mathrm{~mL}$ of water and filtered through a $0.22 \mu \mathrm{m}$ nylon membrane filter. For the cereal and low-calorie food samples, the residues were dissolved in $2.0 \mathrm{~mL}$ of water and filtered accordingly prior to HPLC-DAD analysis. The injection volume was $20 \mu \mathrm{L}$.

For multi-vitamin pills, $10 \mathrm{mg}$ of sample was weighed into a $15 \mathrm{~mL}$ plastic tube with $10.0 \mathrm{~mL}$ of water. For vitamin drinks, $1.0 \mathrm{~mL}$ of sample was placed in a plastic tube with $1.0 \mathrm{~mL}$ of water. The suspensions were filtered through a $0.22 \mu \mathrm{m}$ nylon membrane filter after vortexing, and $20 \mu \mathrm{L}$ of filtrate was injected for HPLC-DAD analysis. An external standard calibration method was used to quantify the six B group vitamins.

Method Validation. Calibration curves were created by plotting peak areas against six corresponding concentrations $(\mu \mathrm{g} / \mathrm{mL})$ of each vitamin. A series of standard mixture solutions were injected in triplicate $(n=3)$. The intra- and interday precisions of the six vitamins were assessed at three different concentrations within the linear range of the calibration curves, calculating the relative standard deviation (coefficient of variation, CV). The intra- and inter-day accuracies were also determined at three different concentrations used to prepare calibration curves and are expressed as an observed concentration relative to a nominal concentration. The limits of quantification (LOQ) were determined as the concentrations where the signal-to-noise $(\mathrm{S} / \mathrm{N})$ ratio was greater than 10 , with a precision of $<20 \%$ and an accuracy between $80-120 \% .^{32}$

Recovery Assay. Recoveries were determined according to the standard addition procedure at three different concentrations $(0.2,0.4$, and $1.0 \mu \mathrm{g} / \mathrm{mL}$ for $\mathrm{T}, \mathrm{RF}$ and $\mathrm{PN}, 2.0,4.0$, and $10.0 \mu \mathrm{g} / \mathrm{mL}$ for NA, $0.5,1.0$, and $2.5 \mu \mathrm{g} / \mathrm{mL}$ for PA and $0.1,0.2$, and $0.5 \mu \mathrm{g} / \mathrm{mL}$ for FA).

For infant formula, cereal and low-calorie foods, $1.0 \mathrm{~mL}$ of standard solution $(1.0,2.0$, and $5.0 \mu \mathrm{g} / \mathrm{mL}$ for $\mathrm{T}, \mathrm{RF}$ and PN, 10.0, 20.0, and $50.0 \mu \mathrm{g} / \mathrm{mL}$ for NA, 2.5, 5.0, and 12.5 $\mu \mathrm{g} / \mathrm{mL}$ for PA, or $0.5,1.0$, and $2.5 \mu \mathrm{g} / \mathrm{mL}$ for FA) was transferred to a $15 \mathrm{~mL}$ plastic tube with $0.5 \mathrm{~g}$ of sample. The mixtures were mixed thoroughly, incubated for $5 \mathrm{~min}$ and diluted with $1.0 \mathrm{~mL}$ of water. For the multi-vitamin pills, 1.0 $\mathrm{mL}$ of standard solution $(2.0,4.0$, and $10.0 \mu \mathrm{g} / \mathrm{mL}$ for $\mathrm{T}, \mathrm{RF}$ and PN, 20.0, 40.0, and $100.0 \mu \mathrm{g} / \mathrm{mL}$ for NA, 5.0, 10.0, and $25.0 \mu \mathrm{g} / \mathrm{mL}$ for PA, or $1.0,2.0$, and $5.0 \mu \mathrm{g} / \mathrm{mL}$ for FA) was placed in a $15 \mathrm{~mL}$ plastic tube with $10 \mathrm{mg}$ of sample. The mixtures were homogenized, incubated for $5 \mathrm{~min}$ and diluted with $9.0 \mathrm{~mL}$ of water. For the vitamin drinks, $1.0 \mathrm{~mL}$ of standard solution $(0.4,0.8$, and $2.0 \mu \mathrm{g} / \mathrm{mL}$ for T, RF and PN, 4.0, 8.0, and $20.0 \mu \mathrm{g} / \mathrm{mL}$ for NA, $1.0,2.0$, and $5.0 \mu \mathrm{g} / \mathrm{mL}$ for PA, or $0.2,0.4$, and $1.0 \mu \mathrm{g} / \mathrm{mL}$ for FA) was transferred to a $15 \mathrm{~mL}$ plastic tube with no water and $1.0 \mathrm{~mL}$ of sample. The samples were mixed vigorously and incubated for 5 min. All other sample preparation was as described in 'Sample Preparation and Quantification' section.

Recovery was evaluated by calculating the peak area ratios of the vitamin samples spiked with standard and the vitamin standards alone (same concentration used to spike the sample). Six determinations were replicated for each concentration.

Stability Study. The storage stabilities of T, RF, NA, PA, PN and FA were evaluated using two factors, photo-stability and thermo-stability. For these studies, working standard solutions were stored at $4{ }^{\circ} \mathrm{C}$ in daylight, $4{ }^{\circ} \mathrm{C}$ in the dark, $25^{\circ} \mathrm{C}$ in daylight and $25^{\circ} \mathrm{C}$ in the dark for $1,2,3,5,10$ and 15 days. A supplementary examination was performed for other B group vitamins (nicotinic acid, biotin and cyanocobalamin) at the same conditions. Working standard solutions, each containing $40 \mu \mathrm{g} / \mathrm{mL}$ of T, $60 \mu \mathrm{g} / \mathrm{mL}$ of RF, 500 $\mu \mathrm{g} / \mathrm{mL}$ of NA, $300 \mu \mathrm{g} / \mathrm{mL}$ of PA, $40 \mu \mathrm{g} / \mathrm{mL}$ of PN, $10 \mu \mathrm{g} /$ $\mathrm{mL}$ of FA, $500 \mu \mathrm{g} / \mathrm{mL}$ of nicotinic acid, $6 \mu \mathrm{g} / \mathrm{mL}$ of biotin and $10 \mu \mathrm{g} / \mathrm{mL}$ of cyanocobalamin, were used as the test solutions.

\section{Results and Discussion}

Optimization of the Liquid Chromatographic Separa- 
tion of Vitamins. The column packing material influences the development of an HPLC method. Several stationary phases have been used to separate water-soluble vitamins, like $\mathrm{C}_{18}$-reverse phase, reverse phase with ion-pairing reagent, normal phase, ion exchange phase and special bonded phase. ${ }^{33}$ Generally, $\mathrm{C}_{18}$-reverse phase has been considered the gold standard in vitamin analysis, due to its simplicity and ruggedness. If there are very different polarities of vitamins, however, a more suitable column must be used.

In the present study, six reverse-phase chromatographic columns: Luna $\mathrm{C}_{5}$, Luna $\mathrm{C}_{8}$, Synergi Polar-RP, Ascentis Express $\mathrm{C}_{18}$, Hypersil Gold $\mathrm{C}_{18}$ and Develosil RPAQUEOUS $\mathrm{C}_{30}$, were compared on the basis of chromatographic separation and sensitivity in order to evaluate column performance (data not shown). Analytes were detected at $210 \mathrm{~nm}$ as a trial. Develosil RPAQUEOUS $\mathrm{C}_{30}$ surpassed other columns in chromatographic separation and sensitivity and was the most suitable for the separation all the six vitamins (T, RF, NA, PA, PN and FA) from various matrices in a single run.

The $\mathrm{C}_{30}$-reverse phase column is known to be more retentive for very hydrophilic compounds than are the $\mathrm{C}_{18}$ columns. ${ }^{34} \mathrm{C}_{30}$ is also more resistant to phase collapse under highly aqueous conditions than are those of $\mathrm{C}_{18} \cdot{ }^{35}$ The column used in this study separated not only the six B vitamins of interest but also three other water-soluble vitamins (nicotinic acid, biotin and cyanocobalamin) at 210 nm (Figure 1).

Four different column temperatures $\left(25^{\circ} \mathrm{C}, 30^{\circ} \mathrm{C}, 35^{\circ} \mathrm{C}\right.$ and $40{ }^{\circ} \mathrm{C}$ ) were tested to maximize peak symmetry and sharpness. Optimal separation of the chosen $\mathrm{B}$ group vitamins was achieved at $30^{\circ} \mathrm{C}$, and this temperature was used for all other experiments.

A mobile phase containing a potassium phosphate buffer is recommended to assure good chromatographic separation of water-soluble vitamins. The influence of potassium phosphate at concentrations from 10 to $50 \mathrm{mM}$ and $\mathrm{pH} 2.5$ to 3.1 and 6.0 to 7.0 (data not shown) was assessed to optimize the mobile phase. The optimized buffer conditions were $20 \mathrm{mM}$ potassium phosphate at $\mathrm{pH} 3.0$.

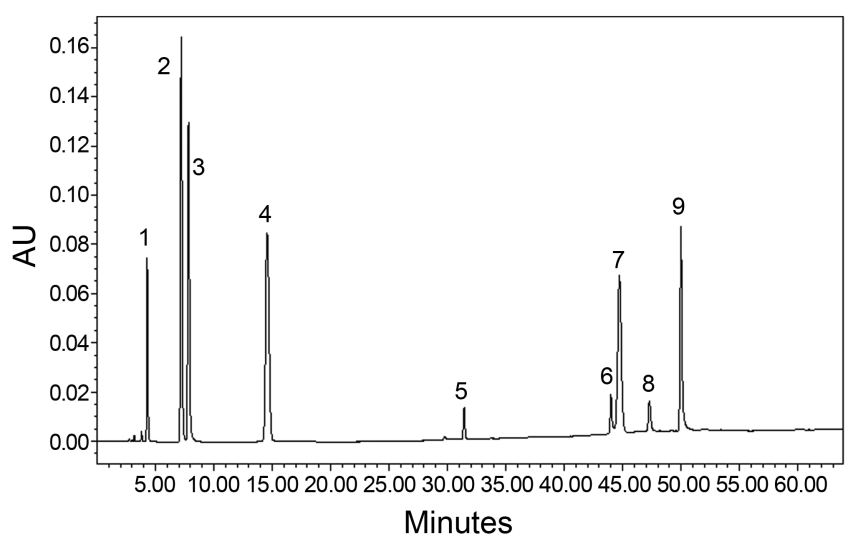

Figure 1. HPLC-DAD chromatogram of the B group vitamin standards using a Develosil RPAQUEOUS $\mathrm{C}_{30}(4.6 \mathrm{~mm} \times 250 \mathrm{~mm}$, $5 \mu \mathrm{m}$ particle size) column at $210 \mathrm{~nm}$ (1: T, 2: NA, 3: nicotinic acid*, 4: PN, 5: PA, 6: FA, 7: cyanocobalamin*, 8: biotin*, and 9: $\mathrm{RF})$. *Reference water-soluble vitamin.
Isocratic and gradient elution have been used to separate water-soluble vitamins. Primarily, we attempted to separate six vitamins using isocratic elution with $20 \mathrm{mM}$ potassium phosphate buffer (pH 3.0). Baseline separation of T, NA and PN was achieved, but the other three vitamins (PA, FA and $\mathrm{RF}$ ) did not elute. Thus, we applied gradient elution to separate all analytes and to shorten the analysis time using $20 \mathrm{mM}$ potassium phosphate at $\mathrm{pH} 3.0$ (solvent $\mathrm{A}$ ) and $50 \%$ acetonitrile $(\mathrm{v} / \mathrm{v})$ in $20 \mathrm{mM}$ potassium phosphate at $\mathrm{pH} 3.0$ (solvent B). The optimal gradient elution was as follows: 1) an initial isocratic step with $100 \%$ solvent A for $10 \mathrm{~min}$ at a flow rate of $0.8 \mathrm{~mL} / \mathrm{min} ; 2) 100 \%$ solvent $\mathrm{A}$ at an increased flow rate of $1.0 \mathrm{~mL} / \mathrm{min}$ for $2 \mathrm{~min}$; 3 ) a linear gradient to $50 \%$ solvent $\mathrm{A} / 50 \%$ solvent $\mathrm{B}$ over $48 \mathrm{~min}$ at $1.0 \mathrm{~mL} / \mathrm{min}$. Initially there should be no acetonitrile in the mobile phase in order to retain thiamine (T) and to avoid column dead time $\left(\mathrm{t}_{0}\right)$.

All vitamins were detected at $275 \mathrm{~nm}$ except for PA, which absorbs at a lower wavelength due to its lack of a

Table 2. Linearities $(n=3)$ and quantification limits for the B group vitamins

\begin{tabular}{ccccc}
\hline Compound & $\begin{array}{c}\text { Linear } \\
\text { range } \\
(\mu \mathrm{g} / \mathrm{g})\end{array}$ & $\begin{array}{c}\text { Regression } \\
\text { equation }\end{array}$ & $\begin{array}{c}\text { Correlation } \\
\text { coefficient } \\
\left(r^{2}\right)\end{array}$ & $\begin{array}{c}\text { LOQ } \\
(\mu \mathrm{g} / \mathrm{g})\end{array}$ \\
\hline $\mathrm{T}$ & $0.2 \sim 10.0$ & $\mathrm{y}=35627 \mathrm{x}-1957.5$ & 0.999 & 0.2 \\
$\mathrm{RF}$ & $0.2 \sim 10.0$ & $\mathrm{y}=93432 \mathrm{x}+90.245$ & 0.999 & 0.2 \\
$\mathrm{NA}$ & $2.0 \sim 100.0 \mathrm{y}=12299 \mathrm{x}+391.62$ & 1.000 & 2.0 \\
$\mathrm{PA}$ & $0.5 \sim 25.0 \quad \mathrm{y}=14087 \mathrm{x}+4111.6$ & 0.999 & 0.5 \\
$\mathrm{PN}$ & $0.2 \sim 10.0$ & $\mathrm{y}=26665 \mathrm{x}+418.26$ & 0.999 & 0.2 \\
$\mathrm{FA}$ & $0.1 \sim 5.0$ & $\mathrm{y}=38949 \mathrm{x}-2389$ & 0.996 & 0.1 \\
\hline
\end{tabular}

Table 3. Intra- and inter-day precisions and accuracies of the B group vitamins $(\mathrm{n}=3)$

\begin{tabular}{cccccc}
\hline \multirow{2}{*}{ Compound $\begin{array}{c}\text { Concentration } \\
(\mu \mathrm{g} / \mathrm{g})\end{array}$} & \multicolumn{2}{c}{ Precision $(\mathrm{CV}, \%)$} & \multicolumn{2}{c}{ Accuracy $(\%)$} \\
\cline { 3 - 6 } & 0.2 & 5.68 & 3.58 & 104 & 109 \\
\hline \multirow{2}{*}{$\mathrm{T}$} & 1 & 4.26 & 2.83 & 99.5 & 101 \\
& 10 & 0.379 & 0.475 & 99.1 & 99.0 \\
\hline \multirow{3}{*}{$\mathrm{RF}$} & 0.2 & 0.560 & 0.386 & 103 & 103 \\
& 1 & 1.39 & 0.950 & 99.8 & 101 \\
& 10 & 0.780 & 1.98 & 104 & 102 \\
\hline \multirow{3}{*}{$\mathrm{NA}$} & 2 & 1.91 & 4.10 & 94.3 & 98.6 \\
& 10 & 2.45 & 1.27 & 97.8 & 101 \\
& 100 & 0.618 & 1.18 & 97.5 & 99.2 \\
\hline \multirow{3}{*}{$\mathrm{PA}$} & 0.5 & 0.620 & 3.04 & 98.2 & 99.6 \\
& 2.5 & 1.04 & 0.496 & 99.4 & 99.4 \\
& 25 & 0.101 & 0.953 & 99.2 & 100 \\
\hline \multirow{2}{*}{$\mathrm{PN}$} & 0.2 & 3.44 & 2.41 & 96.1 & 98.9 \\
& 1 & 1.99 & 1.40 & 100 & 101 \\
& 10 & 0.447 & 1.00 & 99.2 & 99.8 \\
\hline \multirow{2}{*}{$\mathrm{FA}$} & 0.1 & 5.06 & 4.27 & 111 & 103 \\
& 0.5 & 4.68 & 7.97 & 95.0 & 96.2 \\
& 5 & 6.99 & 7.83 & 87.2 & 89.4 \\
\hline
\end{tabular}


characteristic chromophore. PA was detected at $205 \mathrm{~nm}$. We also varied the flow rates from $0.8 \mathrm{~mL} / \mathrm{min}$ to $1 \mathrm{~mL} / \mathrm{min}$ under a flow rate gradient to better separate $\mathrm{T}$ and NA. The elution order was found to be T, NA, PN, PA, FA and RF.

Validation of the Analytical Method: Linearity, Limit of Quantification (LOQ), Intra- and Inter-day Precision and Accuracy, Recovery and Stability. The proposed method was validated by assessing the linearity, limit of quantification (LOQ), intra- and inter-day precision, accuracy, recovery and stability. Sufficient linearity was observed for all six vitamins within the tested concentration ranges, as represented by the high correlation coefficients $\left(r^{2}\right)$ values above 0.995 . The limits of quantification (LOQ) were 0.1 $\mu \mathrm{g} / \mathrm{mL}$ for FA, $0.2 \mu \mathrm{g} / \mathrm{mL}$ for $\mathrm{T}$, RF and $\mathrm{PN}, 0.5 \mu \mathrm{g} / \mathrm{mL}$ for $\mathrm{PA}$, and $2.0 \mu \mathrm{g} / \mathrm{mL}$ for NA (Table 2).

Table 4. Recovery of B group vitamins in infant formula and cereal $(\mathrm{n}=6)$

\begin{tabular}{|c|c|c|c|c|}
\hline \multirow{2}{*}{ Sample } & \multirow{2}{*}{ Vitamin } & \multirow{2}{*}{$\begin{array}{c}\text { Spiked } \\
\text { concentration } \\
(\mu \mathrm{g} / \mathrm{g})\end{array}$} & \multicolumn{2}{|c|}{ Recovery (\%) } \\
\hline & & & Mean & $\mathrm{RSD}^{a}$ \\
\hline \multirow{18}{*}{$\begin{array}{l}\text { Infant } \\
\text { formula }\end{array}$} & \multirow{3}{*}{$\mathrm{T}$} & 0.2 & 104 & 8.62 \\
\hline & & 0.4 & 102 & 9.56 \\
\hline & & 1.0 & 100 & 5.88 \\
\hline & \multirow{3}{*}{$\mathrm{RF}$} & 0.2 & 96.4 & 5.67 \\
\hline & & 0.4 & 102 & 8.69 \\
\hline & & 1.0 & 99.3 & 4.18 \\
\hline & \multirow{3}{*}{ NA } & 2.0 & 99.4 & 2.95 \\
\hline & & 4.0 & 102 & 3.42 \\
\hline & & 10.0 & 100 & 2.72 \\
\hline & \multirow{3}{*}{$\mathrm{PA}$} & 0.5 & - & - \\
\hline & & 1.0 & - & - \\
\hline & & 2.5 & - & - \\
\hline & \multirow{3}{*}{ PN } & 0.2 & 103 & 9.30 \\
\hline & & 0.4 & 97.4 & 7.36 \\
\hline & & 1.0 & 100 & 9.38 \\
\hline & \multirow{3}{*}{ FA } & 0.1 & - & - \\
\hline & & 0.2 & - & - \\
\hline & & 0.5 & - & - \\
\hline \multirow{15}{*}{ Cereal } & \multirow{3}{*}{$\mathrm{T}$} & 0.2 & 99.8 & 8.74 \\
\hline & & 0.4 & 102 & 3.01 \\
\hline & & 1.0 & 96.7 & 3.25 \\
\hline & \multirow{3}{*}{$\mathrm{RF}$} & 0.2 & 100 & 5.12 \\
\hline & & 0.4 & 102 & 3.49 \\
\hline & & 1.0 & 101 & 2.85 \\
\hline & \multirow{3}{*}{ NA } & 2.0 & 91.8 & 9.79 \\
\hline & & 4.0 & 98.7 & 7.23 \\
\hline & & 10.0 & 101 & 5.22 \\
\hline & \multirow{3}{*}{$\mathrm{PN}$} & 0.2 & 98.3 & 8.29 \\
\hline & & 0.4 & 104 & 5.26 \\
\hline & & 1.0 & 99.3 & 10.9 \\
\hline & \multirow{3}{*}{ FA } & 0.1 & 97.2 & 8.05 \\
\hline & & 0.2 & 94.6 & 7.94 \\
\hline & & 0.5 & 89.8 & 6.50 \\
\hline
\end{tabular}

${ }^{a}$ Relative standard deviation. -: not quantified due to the interference of the matrix.
The intra- and inter-day precisions and accuracies were assessed from repeated experiments $(n=3)$ at three different concentrations of the six vitamins. The intra-day precision was $0.10-6.99 \%$, and the inter-day precision was 0.39 $7.97 \%$. The intra-day accuracy was $87.15-110.96 \%$, and the inter-day accuracy was $89.38-108.56 \%$ (Table 3). All accuracy and precision values for the six vitamins fell within the acceptable ranges $(<15 \%)$.

A recovery assay was performed according to the standard addition procedure at three different concentrations. Recovery was assessed from repeated experiments $(n=6)$ using four different supplemented food products: infant formula, cereal, multi-vitamin pills and vitamin drinks (Tables 4 and 5).

Table 5. Recovery of B group vitamins in multi-vitamin pills and vitamin drinks $(n=6)$

\begin{tabular}{|c|c|c|c|c|}
\hline \multirow{2}{*}{ Sample } & \multirow{2}{*}{ Vitamin } & \multirow{2}{*}{$\begin{array}{c}\text { Spiked } \\
\text { concentration } \\
(\mu \mathrm{g} / \mathrm{g})\end{array}$} & \multicolumn{2}{|c|}{ Recovery (\%) } \\
\hline & & & Mean & RSD \\
\hline \multirow{18}{*}{$\begin{array}{c}\text { Multi- } \\
\text { vitamin pill }\end{array}$} & \multirow{3}{*}{$\mathrm{T}$} & 0.2 & 98.4 & 1.39 \\
\hline & & 0.4 & 97.7 & 1.64 \\
\hline & & 1.0 & 100 & 0.882 \\
\hline & \multirow{3}{*}{$\mathrm{RF}$} & 0.2 & 99.0 & 1.58 \\
\hline & & 0.4 & 99.5 & 0.953 \\
\hline & & 1.0 & 99.3 & 0.958 \\
\hline & \multirow{3}{*}{ NA } & 2.0 & 99.6 & 1.35 \\
\hline & & 4.0 & 99.6 & 1.61 \\
\hline & & 10.0 & 99.4 & 0.630 \\
\hline & \multirow{3}{*}{ PA } & 0.5 & 99.4 & 2.10 \\
\hline & & 1.0 & 99.7 & 1.91 \\
\hline & & 2.5 & 99.8 & 0.986 \\
\hline & \multirow{3}{*}{ PN } & 0.2 & 99.4 & 3.96 \\
\hline & & 0.4 & 100 & 1.06 \\
\hline & & 1.0 & 100 & 1.03 \\
\hline & \multirow{3}{*}{ FA } & 0.1 & 97.2 & 6.73 \\
\hline & & 0.2 & 98.3 & 6.14 \\
\hline & & 0.5 & 95.6 & 3.22 \\
\hline \multirow{18}{*}{$\begin{array}{l}\text { Vitamin } \\
\text { drink }\end{array}$} & \multirow{3}{*}{$\mathrm{T}$} & 0.2 & 100 & 1.20 \\
\hline & & 0.4 & 100 & 1.93 \\
\hline & & 1.0 & 99.9 & 0.356 \\
\hline & \multirow{3}{*}{$\mathrm{RF}$} & 0.2 & 99.5 & 1.49 \\
\hline & & 0.4 & 100 & 0.842 \\
\hline & & 1.0 & 100 & 0.143 \\
\hline & \multirow{3}{*}{ NA } & 2.0 & 100 & 1.68 \\
\hline & & 4.0 & 99.5 & 0.621 \\
\hline & & 10.0 & 100 & 0.429 \\
\hline & \multirow{3}{*}{ PA } & 0.5 & 101 & 1.48 \\
\hline & & 1.0 & 101 & 1.83 \\
\hline & & 2.5 & 99.8 & 1.02 \\
\hline & \multirow{3}{*}{$\mathrm{PN}$} & 0.2 & 98.5 & 2.38 \\
\hline & & 0.4 & 99.6 & 2.69 \\
\hline & & 1.0 & 100 & 1.42 \\
\hline & \multirow{3}{*}{ FA } & 0.1 & 99.5 & 2.56 \\
\hline & & 0.2 & 99.2 & 1.68 \\
\hline & & 0.5 & 100 & 3.81 \\
\hline
\end{tabular}


(a) Thiamine

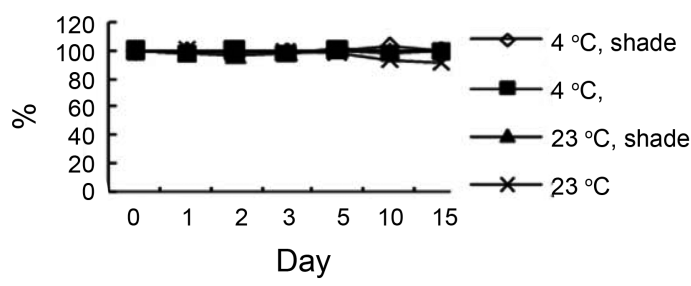

(c)

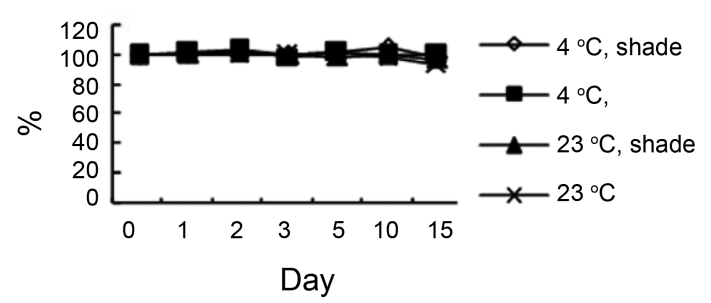

(e)

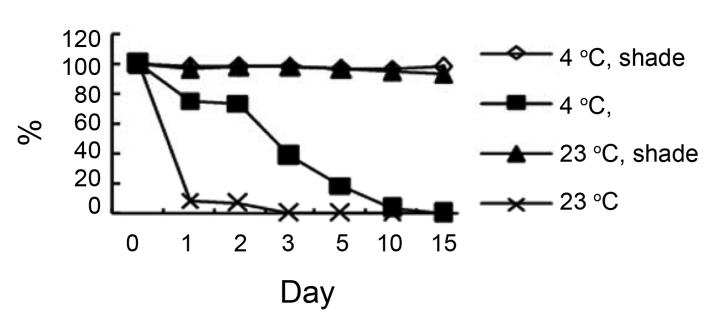

(g)

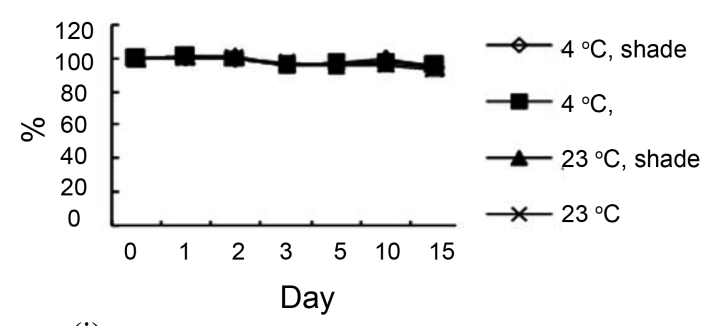

(i)

Cyanocobalamin

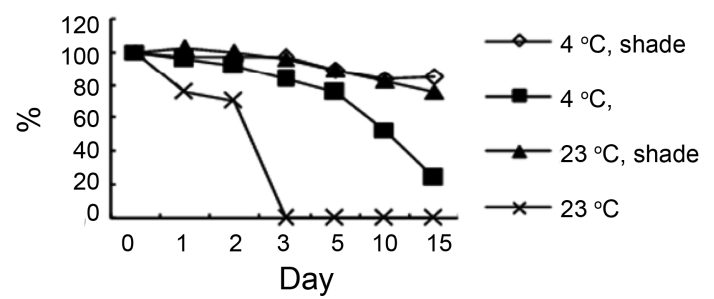

(b) Riboflavin

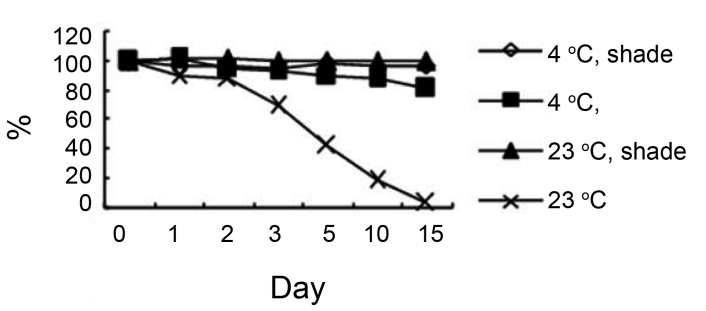

(d) Pantothenic acid

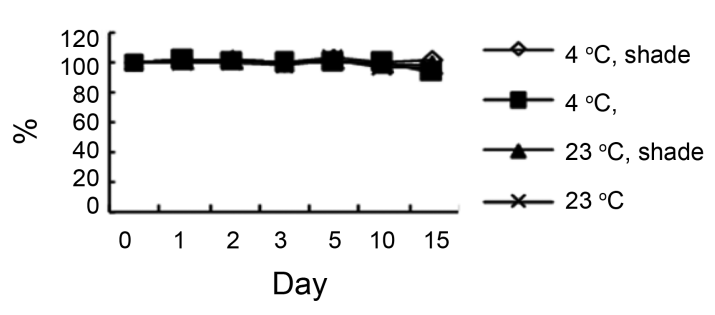

(f)

Folic acid

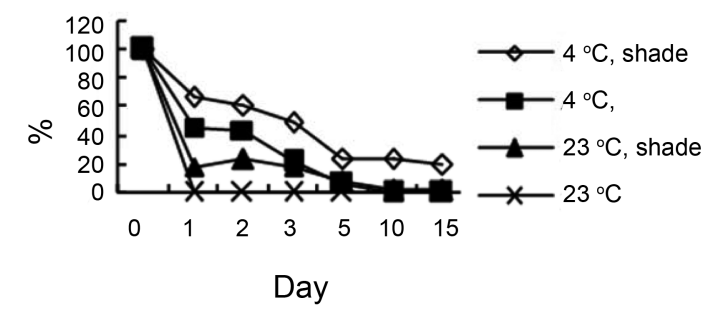

(h)

Biotin

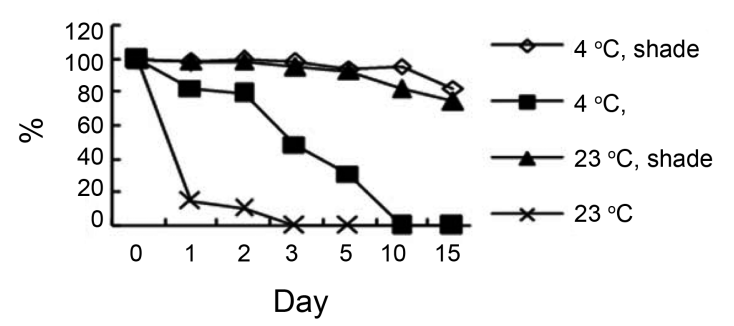

Figure 2. Stabilities of the B group vitamins (a) T, (b) RF, (c) NA, (d) PA, (e) PN and (f) FA and reference water-soluble vitamins (g) nicotinic acid, (h) biotin and (i) cyanocobalamin $\left(\diamond: 4{ }^{\circ} \mathrm{C}\right.$ in the dark, $\mathbf{\square}: 4{ }^{\circ} \mathrm{C}$ in daylight, $\mathbf{\Delta}: 23{ }^{\circ} \mathrm{C}$ in the dark, and $\times: 23{ }^{\circ} \mathrm{C}$ in daylight).

Low-calorie food was excluded from the recovery test because its matrix was similar to that of cereal. Unfortunately, PA and FA were not detected in the infant formula due to its complex matrix, nor was PA detected in the cereal samples, because the cereal and low-calorie food products were not fortified with this vitamin. The mean recoveries of all of the tested vitamins were higher than $96.35 \%$ for infant formula, $89.75 \%$ for cereal, $95.63 \%$ for multi-vitamin pills 
and $98.46 \%$ for vitamin drinks. Recoveries were high due to the simple sample preparation method in mild conditions.

The stabilities of the six B vitamins and three other water soluble vitamins were studied by storing the nine vitamin standard solutions under different conditions: $4{ }^{\circ} \mathrm{C}$ in daylight, $4{ }^{\circ} \mathrm{C}$ in the dark, $23{ }^{\circ} \mathrm{C}$ in daylight and $23{ }^{\circ} \mathrm{C}$ in the dark for 1, 2, 3, 5, 10 and 15 days (Figure 2). T, NA, PA and nicotinic acid were the most stable under both light and heat for 15 days. PN, biotin and cyanocobalamin were only stable in the dark. RF was less stable in both light and increased heat, although it is stable against limited exposure. FA was the most unstable in all light and heat conditions and had almost completely degraded after one day of simultaneous exposure to light and heat. Therefore, HPLC-DAD measurements must be performed immediately, and vitamin solutions are best stored at $-20{ }^{\circ} \mathrm{C}$ in subdued light in order to maintain their stabilities.

Food Sample Analysis. Due to the extensive phosphorylated and protein-bound vitamins in natural foods, quantitative analysis of the entire array of B-group vitamins at endogenous levels requires vigorous sample extraction to release the free vitamins using strong acids and enzyme hydrolysis. ${ }^{19-30}$ However, these tedious, complex and harsh methods are not necessary to extract the vitamins from vitamin-supplemented food products.

The most rapid extraction methods of water-soluble vitamins from food products involve protein precipitation using a strong acid, such as hydrochloric acid, sulfuric acid or trichloroacetic acid. ${ }^{19-22,24,25,27,30}$ Interference in the chromatograms and poor recovery indicate degradation of some vitamins due to the harsh acid. Organic solvents can also be used to precipitate proteins and are milder toward the
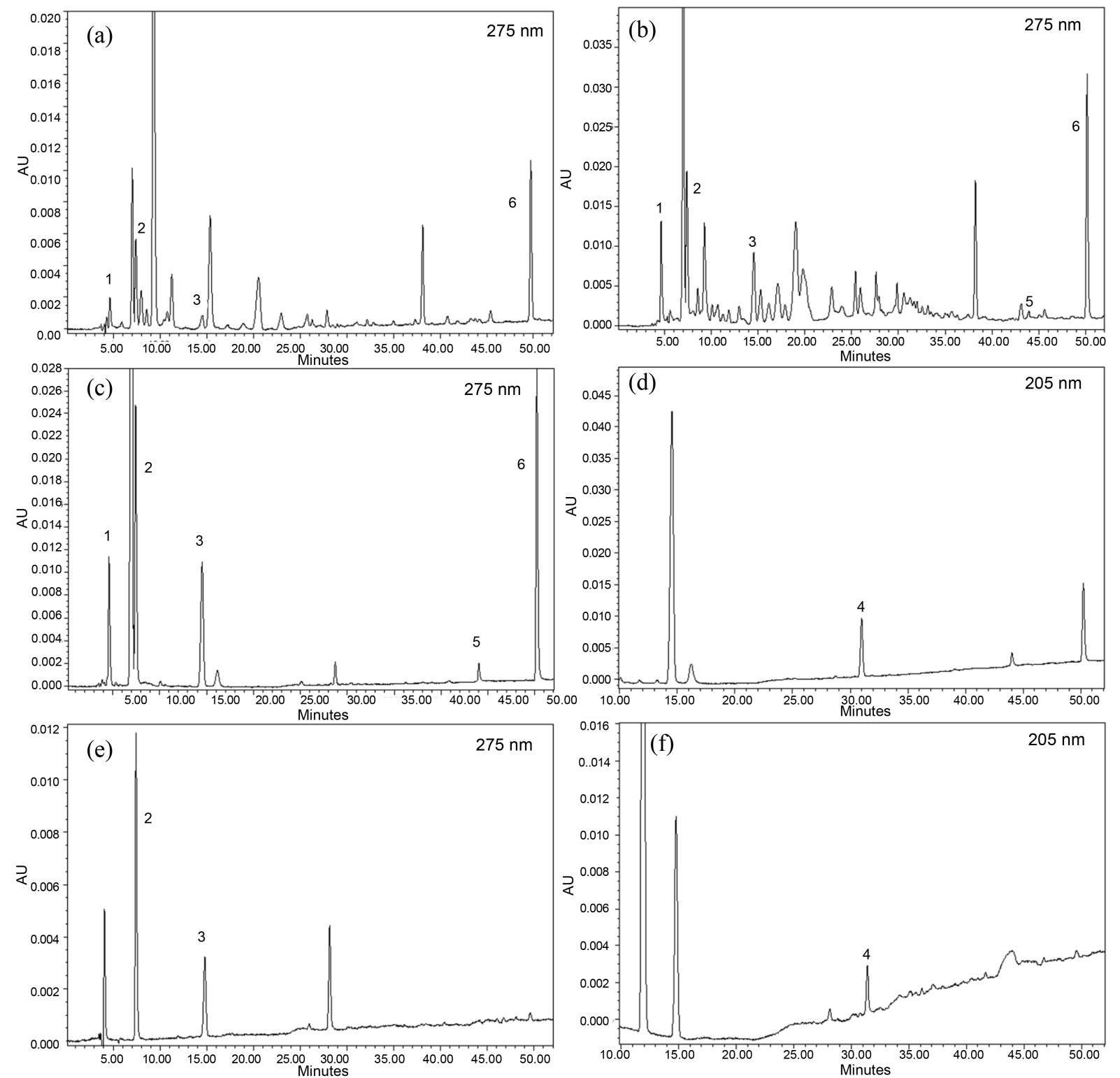

Figure 3. Simultaneous determination of B group vitamins (a) in infant formula at $275 \mathrm{~nm}$, (b) in cereal at $275 \mathrm{~nm}$, (c) in multi-vitamin pills at $275 \mathrm{~nm},(\mathrm{~d})$ in multi-vitamin pills at $205 \mathrm{~nm}$, (e) in vitamin drinks at $275 \mathrm{~nm}$, and (f) in vitamin drinks at 205 nm (1: T, 2: NA, 3: PN, 4: PA, 5: FA and 6: RF). 
Table 6. Analytical results of the vitamin content in infant formulas, cereals, low-calorie foods, multi-vitamin pills and vitamin drinks (n=3)

\begin{tabular}{|c|c|c|c|c|c|c|}
\hline \multirow{2}{*}{ Sample } & \multicolumn{6}{|c|}{ Vitamin found $^{a}$ (labeled) $(\mu \mathrm{g} / \mathrm{g})$} \\
\hline & $\mathrm{T}$ & $\mathrm{RF}$ & NA & PA & $\mathrm{PN}$ & FA \\
\hline Infant formula 1 & $\begin{array}{c}4.87 \pm 0.05 \\
(4.5)\end{array}$ & $\begin{array}{l}11.50 \pm 0.13 \\
(6)\end{array}$ & $\begin{array}{c}49.02 \pm 0.54 \\
(50)\end{array}$ & - & $\begin{array}{c}3.63 \pm 0.13 \\
\text { (3) }\end{array}$ & - \\
\hline Infant formula 2 & $\begin{array}{c}5.47 \pm 0.13 \\
\text { (6) }\end{array}$ & $\begin{array}{c}10.36 \pm 0.05 \\
(8)\end{array}$ & $\begin{array}{c}60.77 \pm 0.56 \\
(60)\end{array}$ & - & $\begin{array}{l}5.71 \pm 0.12 \\
(6)\end{array}$ & - \\
\hline Infant formula 3 & $\begin{array}{c}9.62 \pm 0.02 \\
(10)\end{array}$ & $\begin{array}{c}10.38 \pm 0.06 \\
\quad(10)\end{array}$ & $\begin{array}{c}60.40 \pm 0.46 \\
(60)\end{array}$ & - & $\begin{array}{c}3.46 \pm 0.13 \\
\text { (4) }\end{array}$ & - \\
\hline Infant formula 4 & $\begin{array}{c}5.00 \pm 0.05 \\
(5)\end{array}$ & $\begin{array}{c}7.74 \pm 0.03 \\
(9)\end{array}$ & $\begin{array}{c}49.68 \pm 0.44 \\
(53)\end{array}$ & - & $\begin{array}{c}5.21 \pm 0.04 \\
(5)\end{array}$ & - \\
\hline Infant formula 5 & $\begin{array}{l}5.27 \pm 0.10 \\
\text { (3) }\end{array}$ & $\begin{array}{c}10.20 \pm 0.09 \\
(6)\end{array}$ & $\begin{array}{c}53.87 \pm 0.25 \\
(50)\end{array}$ & - & $\begin{array}{c}4.62 \pm 0.07 \\
\text { (3) }\end{array}$ & - \\
\hline Infant formula 6 & $\begin{array}{c}5.10 \pm 0.10 \\
(5)\end{array}$ & $\begin{array}{c}8.93 \pm 0.10 \\
(8)\end{array}$ & $\begin{array}{c}57.33 \pm 0.41 \\
(58)\end{array}$ & - & $\begin{array}{c}3.26 \pm 0.02 \\
(3.15)\end{array}$ & - \\
\hline Infant formula 7 & $\begin{array}{c}2.802 \pm 0.004 \\
(2.3)\end{array}$ & $\begin{array}{c}7.27 \pm 0.03 \\
(4.6)\end{array}$ & $\begin{array}{c}40.11 \pm 0.43 \\
(37)\end{array}$ & - & $\begin{array}{c}2.62 \pm 0.05 \\
\quad(2.3)\end{array}$ & - \\
\hline Infant formula 8 & $\begin{array}{l}2.87 \pm 0.04 \\
(2.3)\end{array}$ & $\begin{array}{c}7.37 \pm 0.05 \\
(4.6)\end{array}$ & $\begin{array}{c}42.30 \pm 0.06 \\
(40)\end{array}$ & - & $\begin{array}{c}2.76 \pm 0.02 \\
(2.3)\end{array}$ & - \\
\hline Infant formula 9 & $\begin{array}{l}6.13 \pm 0.11 \\
(5.29)\end{array}$ & $\begin{array}{c}13.38 \pm 0.19 \\
(11.66)\end{array}$ & $\begin{array}{c}55.82 \pm 0.17 \\
(55.2)\end{array}$ & - & $\begin{array}{c}3.41 \pm 0.02 \\
(3.19)\end{array}$ & - \\
\hline Infant formula 10 & $\begin{array}{c}5.40 \pm 0.08 \\
\text { (4) }\end{array}$ & $\begin{array}{c}6.76 \pm 0.09 \\
(6)\end{array}$ & $\begin{array}{c}50.84 \pm 0.16 \\
(50)\end{array}$ & - & $\begin{array}{c}4.88 \pm 0.05 \\
\text { (4) }\end{array}$ & - \\
\hline Cereal 1 & $\begin{array}{l}23.18 \pm 0.14 \\
\quad(8.33)\end{array}$ & $\begin{array}{c}11.37 \pm 0.15 \\
(10)\end{array}$ & $\begin{array}{c}137.24 \pm 1.69 \\
(108.3)\end{array}$ & $\begin{array}{l}\text { ND } \\
\text { (nd) }\end{array}$ & $\begin{array}{c}18.65 \pm 0.19 \\
(12.67)\end{array}$ & $\begin{array}{c}1.64 \pm 0.02 \\
(2.08)\end{array}$ \\
\hline Cereal 2 & $\begin{array}{c}11.83 \pm 0.26 \\
(8)\end{array}$ & $\begin{array}{c}11.92 \pm 0.10 \\
(9.5)\end{array}$ & $\begin{array}{c}115.40 \pm 1.65 \\
(106.5)\end{array}$ & $\begin{array}{l}\mathrm{ND} \\
\text { (nd) }\end{array}$ & $\begin{array}{c}18.28 \pm 0.11 \\
\quad(9.5)\end{array}$ & $\begin{array}{c}1.32 \pm 0.05 \\
\quad(1.55)\end{array}$ \\
\hline Cereal 3 & $\begin{array}{c}29.01 \pm 0.34 \\
(8.33)\end{array}$ & $\begin{array}{c}13.83 \pm 0.07 \\
(10)\end{array}$ & $\begin{array}{c}160.32 \pm 1.23 \\
(108.3)\end{array}$ & $\begin{array}{l}\mathrm{ND} \\
\text { (nd) }\end{array}$ & $\begin{array}{c}20.32 \pm 0.43 \\
\quad(12.67)\end{array}$ & $\begin{array}{c}1.91 \pm 0.01 \\
(2.08)\end{array}$ \\
\hline $\begin{array}{l}\text { Low-calorie } \\
\text { food } 1\end{array}$ & $\begin{array}{l}12.72 \pm 0.25 \\
(3.95)\end{array}$ & $\begin{array}{c}14.65 \pm 0.03 \\
\quad(4.74)\end{array}$ & $\begin{array}{c}69.62 \pm 0.73 \\
(51.3)\end{array}$ & $\begin{array}{l}\mathrm{ND} \\
\text { (nd) }\end{array}$ & $\begin{array}{c}23.89 \pm 0.12 \\
(5.92)\end{array}$ & $\begin{array}{l}0.77 \pm 0.01 \\
\quad(0.99)\end{array}$ \\
\hline $\begin{array}{l}\text { Low-calorie } \\
\quad \text { food } 2\end{array}$ & $\begin{array}{l}12.84 \pm 0.13 \\
(3.95)\end{array}$ & $\begin{array}{l}14.93 \pm 0.06 \\
(4.74)\end{array}$ & $\begin{array}{c}63.20 \pm 1.13 \\
(51.3)\end{array}$ & $\begin{array}{l}\text { ND } \\
\text { (nd) }\end{array}$ & $\begin{array}{l}22.97 \pm 0.61 \\
\quad(5.92)\end{array}$ & $\begin{array}{l}0.83 \pm 0.01 \\
(0.99)\end{array}$ \\
\hline $\begin{array}{l}\text { Low-calorie } \\
\quad \text { food } 3\end{array}$ & $\begin{array}{c}12.41 \pm 0.21 \\
(3.95)\end{array}$ & $\begin{array}{c}15.49 \pm 0.01 \\
(4.74)\end{array}$ & $\begin{array}{c}59.18 \pm 0.77 \\
(51.3)\end{array}$ & $\begin{array}{l}\mathrm{ND} \\
\text { (nd) }\end{array}$ & $\begin{array}{c}22.13 \pm 0.08 \\
\quad(5.92)\end{array}$ & $\begin{array}{c}0.78 \pm 0.01 \\
\quad(0.99)\end{array}$ \\
\hline $\begin{array}{l}\text { Multi-vitamin } \\
\text { pill } 1\end{array}$ & $\begin{array}{c}309.6 \pm 11.2 \\
(310)\end{array}$ & $\begin{array}{c}375.3 \pm 1.5 \\
(425)\end{array}$ & $\begin{array}{c}2518.4 \pm 34.5 \\
(2255)\end{array}$ & $\begin{array}{l}\mathrm{ND} \\
\text { (nd) }\end{array}$ & $\begin{array}{c}691.73 \pm 12.31 \\
(675)\end{array}$ & $\begin{array}{c}41.60 \pm 1.24 \\
\text { (35) }\end{array}$ \\
\hline $\begin{array}{l}\text { Multi-vitamin } \\
\text { pill } 2\end{array}$ & $\begin{array}{l}\mathrm{ND} \\
\text { (nd) }\end{array}$ & $\begin{array}{c}579.70 \pm 6.11 \\
(570)\end{array}$ & $\begin{array}{l}\mathrm{ND} \\
\text { (nd) }\end{array}$ & $\begin{array}{l}\text { ND } \\
\text { (nd) }\end{array}$ & $\begin{array}{c}844.58 \pm 5.80 \\
(713)\end{array}$ & $\begin{array}{l}\mathrm{ND} \\
\text { (nd) }\end{array}$ \\
\hline $\begin{array}{l}\text { Multi-vitamin } \\
\text { pill } 3\end{array}$ & $\begin{array}{c}2024.6 \pm 78.6 \\
(3200)\end{array}$ & $\begin{array}{c}1085.5 \pm 17.0 \\
(1867)\end{array}$ & $\begin{array}{l}\text { ND } \\
\text { (nd) }\end{array}$ & $\begin{array}{c}2960.7 \pm 80.4 \\
(2534)\end{array}$ & $\begin{array}{c}2218.6 \pm 59.7 \\
(2534)\end{array}$ & $\begin{array}{l}\text { ND } \\
\text { (nd) }\end{array}$ \\
\hline $\begin{array}{l}\text { Multi-vitamin } \\
\text { pill } 4\end{array}$ & $\begin{array}{l}\mathrm{ND} \\
\text { (nd) }\end{array}$ & $\begin{array}{l}\mathrm{ND} \\
\text { (nd) }\end{array}$ & $\begin{array}{l}\mathrm{ND} \\
\text { (nd) }\end{array}$ & $\begin{array}{l}\mathrm{ND} \\
\text { (nd) }\end{array}$ & $\begin{array}{l}\mathrm{ND} \\
\text { (nd) }\end{array}$ & $\begin{array}{c}458.4 \pm 11.3 \\
\quad(444)\end{array}$ \\
\hline Vitamin drink 1 & $\begin{array}{l}\mathrm{ND} \\
\text { (nd) }\end{array}$ & $\begin{array}{l}\mathrm{ND} \\
\text { (nd) }\end{array}$ & $\begin{array}{c}23.83 \pm 0.46 \\
(30)\end{array}$ & $\begin{array}{l}3.82 \pm 0.08 \\
\text { (nd) }\end{array}$ & $\begin{array}{c}4.42 \pm 0.06 \\
\quad(4.5)\end{array}$ & $\begin{array}{l}\mathrm{ND} \\
\text { (nd) }\end{array}$ \\
\hline Vitamin drink 2 & $\begin{array}{l}\text { ND } \\
\text { (nd) }\end{array}$ & $\begin{array}{l}4.62 \pm 0.02 \\
\quad(6.6)\end{array}$ & $\begin{array}{c}24.63 \pm 0.02 \\
(24.3)\end{array}$ & $\begin{array}{l}9.75 \pm 0.02 \\
\quad(9.5)\end{array}$ & $\begin{array}{l}3.23 \pm 0.05 \\
\quad(2.8)\end{array}$ & $\begin{array}{l}\text { ND } \\
\text { (nd) }\end{array}$ \\
\hline Vitamin drink 3 & $\begin{array}{l}\text { ND } \\
\text { (nd) }\end{array}$ & $\begin{array}{l}\mathrm{ND} \\
\text { (nd) }\end{array}$ & $\begin{array}{c}23.34 \pm 0.51 \\
(30)\end{array}$ & $\begin{array}{c}3.38 \pm 0.02 \\
\text { (nd) }\end{array}$ & $\begin{array}{c}4.65 \pm 0.18 \\
(4.5)\end{array}$ & $\begin{array}{l}\mathrm{ND} \\
\text { (nd) }\end{array}$ \\
\hline
\end{tabular}

${ }^{a}$ Mean \pm standard deviation, ND: not detected, nd: not declared. -: not quantified due to the interference of the matrix.

samples. Thus, they are frequently utilized in drug analysis. $^{36}$ Acetonitrile showed superior protein precipitation using a small volume. Thus, we investigated acetonitrile as a protein precipitant of various commercial food products and found improved and reliable recoveries (Tables 4 and 5).

The B group vitamins were quantified in different food matrices including infant formula, cereal, low-calorie food, multi-vitamin pills and vitamin drinks in order to verify the applicability of the proposed method. The chromatographic peaks in each sample were identified by comparing their retention times and UV/Vis spectral data to those of standards obtained under the same conditions, using a diode array detector (DAD).

The analysis of each food sample was performed in tri- 
plicate $(n=3)$ to show the reliability of content analysis. Figure 3 show examples of chromatograms obtained for four specific food samples. Values obtained for infant milks, cereals, low-calorie foods, multi-vitamin pills and vitamin drinks are shown in Table 6. There is no regulation on the upper limit of B group vitamins as food additives. Therefore, most vitamin-enriched products are manufactured with an excess of these vitamins, so that the labeled amounts are accurate at the expiration date. Consequently, most results were slightly higher than the labeled amounts. In some of the tested foods, folic acid levels were lower than the labeled amounts. This result indicates that folic acid was unstable and degraded faster than the other water-soluble vitamins in food products.

\section{Conclusions}

The present study provides a simple, sensitive and reliable technique for simultaneously determining the levels of $\mathrm{T}$, RF, NA, PA, PN and FA in supplemented food products using HPLC-DAD. Strikingly, this methodology is useful for a wide range of solid and liquid food products and vitamins analysis without using ion-pairing reagents. Moreover, we introduced for the first time a $\mathrm{C}_{30}$-reverse phase column for analyzing B group vitamins in fortified foods. This method may apply to the quality control of vitaminenriched food products for food laboratories, manufacturers and regulatory authorities.

Acknowledgments. This research was supported by a grant (08082KFDA103) from the Korea Food and Drug Administration in 2008.

\section{References}

1. Southon, S.; Wright, A. J. A.; Finglas, P. M.; Bailey, A. L.; Loughridge, J. M.; Walker, A. D. Brit. J. Nutr. 1994, 71, 897.

2. Gilpin, R. K.; Pachla, L. A. Anal. Chem. 2003, 75, 2907.

3. Penna, D. D. Science 1999, 285, 375.

4. Blinkhorn, S. Nature 1991, 6313, 13.

5. Combs, G. F. Jr. Vitamins: Fundamental Aspects in Nutrition and Health; Academic Press: San Diego, 2nd ed., 1998.

6. Bernard, M. A.; Nakonezny, P. A.; Kashner, T. M. J. Am. Geriatr. Soc. 1998, 46, 1199.

7. Moreno, P.; Salvado, V. J. Chromatogr. A 2000, 870, 207.

8. Konings, E. J. Assoc. Off. Anal. Chem. Int. 2006, 89, 85.
9. Konings, E. J. Assoc. Off. Anal. Chem. Int. 2007, 90, 21B.

10. Kall, M. A. Food Chem. 2003, 82, 315.

11. De Vries, J. W.; Rader, J. I.; Keagy, P. M.; Hudson, C. A. J. Assoc. Off. Anal. Chem. Int. 2005, 88, 5.

12. Han, J. Y.; Tyler, R. T. J. Agric. Food Chem. 2003, 51, 5315.

13. Assoc. Off. Anal. Chem. International, Official methods of Assoc. Off. Anal. Chem. international, Gaithersburg, 18th ed., 2006.

14. Albala-Hurtado, S.; Veciana-Nogues, M. T.; Vidal-Carou, M. C.; Marine-Font, A. J. Food. Sci. 2001, 66, 1191.

15. Almagro, I.; San Andres, M. P.; Vera, S. Chromatographia 2002, $55,185$.

16. Woollard, D. C.; Indyk, H. E. J. Assoc. Off. Anal. Chem. Int. 2002, $85,945$.

17. Albala-Hurtado, S.; Veciana-Nogues, M. T.; Izquierdo-Pulido, M.; Marine-Font, A. J. Chromatogr. A 1997, 778, 247.

18. Snyder, L. R.; Glajch, J. L.; Kirkland, J. J. Practical HPLC Method Development, 2nd ed.; Wiley-Interscience: New York, 1997.

19. Analytical Methods Committee, Analyst 2000, 125, 353.

20. Arella, F.; Lahely, S.; Bourguignon, J. B.; Hasselmann, C. Food Chem. 1996, 56, 81.

21. La Croix, D. E.; Wolf, W. R.; Kwansa, A. L. Cereal Chem. 2005, $82,277$.

22. La Croix, D. E.; Wolf, W. R.; Chase, G. W. J. Assoc. Off. Anal. Chem. Int. 2002, 85, 654.

23. Barnett, S. A.; Frick, L. W.; Baine, H. M. Anal. Chem. 1980, 52, 610.

24. Holler, U.; Wachter, F.; Wehrli, C.; Fizet, C. J. Chromatogr. B 2006, 831,8 .

25. Barna, E.; Dworschak, E. J. Chromatogr. A 1994, 668, 359.

26. Pakin, C.; Bergaentzle, M.; Hubscher, V.; Aoude-Werner, D.; Hasselmann, C. J. Chromatogr. A 2004, 1035, 87.

27. Rose-Sallin, C.; Blake, C. J.; Genoud, D.; Tagliaferri, E. G. Food Chem. 2001, 73, 473.

28. Mann, D. L.; Ware, G. M.; Bonnin, E.; Eitenmiller, R. R. J. Assoc. Off. Anal. Chem. Int. 2005, 88, 30.

29. Koontz, J. L.; Phillips, K. M.; Wunderlich, K. M.; Exler, J.; Holden, J. M.; Genhardt, S. E.; Haytowitz, D. B. J. Assoc. Off. Anal. Chem. Int. 2005, 88, 805.

30. Tang, X.; Cronin, D. A.; Brunton, N. P. J. Food Compos. Anal. 2006, 19, 831

31. Zafra-Gomez, A.; Garballo, A.; Morales, J. C.; Garcia-Ayuso, L. E. J. Argic. Food Chem. 2006, 54, 4531.

32. Validation of Analytical Procedures, ICH-Q2A, Geneva, 1995.

33. Vinas, P.; Lopez-Erroz, C.; Balsalobre, N.; Hernandez-Cordoba, M. J. Chromatogr. A 2003, 1007, 77.

34. Yoshida, H.; Mizukoshi, T.; Hirayama, K.; Miyano, H. J. Agric. Food Chem. 2007, 55, 551.

35. Nagae, N.; Enami, T.; Doshi, S. LCGC North America 2002, 20 , 964.

36. Wells, D. A. High Throughput Bioanalytical Sample Preparation: Methods and Automation Strategies, Elsevier Science: Amsterdam, 1st ed.; 2003. 